DOI: 10.35218/armca.2021.1.09

\title{
Photographic appropriation vs. Baroque painting expressiveness. Postmodern artistic practices in Benetton advertising
}

\author{
Cătălin Soreanu*
}

\begin{abstract}
In this article we analyze from the perspective of vocabulary and visual language elements the way in which the photographic media provides advertising with one of the most consistent expressive resources. The realism of the image, the endless possibilities in managing the visual composition, the premises of reproductibility and, last but not least, the appetite of an audience eager for technological image, ensured the success of this medium acquisition in the field of advertising expression. The way in which photography is used in advertising mechanisms is, instead, the prerogative of the artistic sphere and it is fully subject to professional standards of design, concept, and realization of the image. In particular, we examine how contemporary advertising becomes the territory where various means of expression contribute in a complementary way to the constitution of the meaning of a work, emphasizing the specific sensitivity of those expressive mediums - namely photography and painting. The case study will approach the activity of Oliviero Toscani and his collaboration with Benetton, materialized in memorable advertising campaigns that have practically rewritten the visual history of contemporary advertising. Using "AIDS - David Kirby" ad from Benetton's "Shock of Reality" advertising campaign from 1992, we will specifically analyze the creative premises and mechanisms that characterize Toscani's creation, the reading conditions of his advertising works, as well as the way in which his creative strategies combine the expressiveness of the referential painting memory with the technological precision of press photography, and the appropriation artistic strategies specific to postmodernity.
\end{abstract}

Keywords: advertising, Benetton, media, Oliviero Toscani, painting, photography.

In the visual culture of 2000s, the Italian company Benetton became synonymous with the unconventional approach and innovation, thanks to the collaboration with the artist Oliviero Toscani, a renowned photographer whose attitude towards the image campaigns of the Italian company has far exceeded the border between art and advertising. Oliviero Toscani studied photography and design in Zurich in the 1960s, being recognized both as a

\footnotetext{
* "George Enescu” National University of Arts, Iasi - 700451, RO
} 
remarkable visual artist ${ }^{1}$, and as the creative force behind some of the most successful brands, such as Esprit, Valentino, Chanel, Fiorucci or Prenatal. The long-term collaboration with Benetton (from 1982 to 2000) promoted them from national quasi-anonymity to global brand status ${ }^{2}$, Toscani dealing with their corporate image, brand identity, and communication strategy ${ }^{3}$.

Oliviero Toscani defined advertising photography in terms of his own artistic creation based on the formula of postmodern appropriation, transforming the photographic image into a visual material, both appropriated and re-signified through a specific process of aesthetification. The complex creative mechanism that we can identify behind his works is, moreover, the result of a deep artistic intentionality that doubles the advertising approach, vitiating the very definition of the dependency relationship between the fields of "art" and "advertising" (regarded as visual disciplines). The images he used for Benetton, as advertising products, relied on the particular discrepancy between the nature of the promoted product and the ideological context that "clothes" the image of the manufacturing company. Presented only with the green logo "United Colors of Benetton", discreetly arranged in the composition and consisting exclusively of printed materials (street posters, billboards, and advertisements for magazines and specialty stores), the ads created by Oliviero Toscani depicted controversial topics of international society, whose major tension lies in their very association with the advertising product.

\section{Brand awareness as main strategy}

Toscani's strategy is simple and straightforward. In the context of postmodern art, in which advertising is defined in its visual dimension as an exponent of the consumer area, the type of social-consumer ideology and derived social behaviours, he avoids the clichés characteristic of commercial advertising, moving towards a form of image support in which the subjects no longer have the product itself as a reference, but the ideology that defines it, which becomes in the end the main subject of the expressive advertising

\footnotetext{
${ }^{1}$ His works have been exhibited at the Venice Art Biennale, San Paolo, the Milan Triennials, Lausanne, Mexico City, Helsinki, Rome, and in countless galleries and museums around the world. He is also the winner of four "Golden Lions" at the Cannes Film Festival, the UNESCO "Grand Prize", two "Grand Prix d'Affichage" etc.

(http://olivierotoscani.com/biografia_en.html (accessed 3/8/2021).

${ }^{2}$ Sociologist Andrea Brocceti considers Benetton to be a representative brand for Italy such as Ferrari, Illy or Versace. Online source: http://www.ericjlyman.com/adageglobal.html (accessed 02/28/2021).

${ }^{3}$ In parallel with his work at Benetton, Oliviero Toscani conceived in 1990 a global publication-store called Colors, and in 1994 he founded Fabrica, an international center for research in art and communication, based in Treviso, Italy. (http://www.fabrica.it/about/ (accessed 2/28/2021)
} 
offer. Toscani systematically avoids advertisements featuring Benetton products (clothing and accessories for young people) or using associative juxtapositional clichés (such as using female models in provocative positions associated with certain products). On the contrary, the Benetton campaigns outline a specific attitude and denote an artistic preoccupation whose depth is defined on two levels as follows: 1) it relates to the advertising market, projecting itself as an alternative image, unconventional, original, ensuring at the same time the functionality and visibility of the advertisement and 2) builds an ideological attitude that is associated in the consumer's behaviour with the quality of Benetton products, a solution whose functionality may seem paradoxical, especially from the perspective of completely excluding the display of (the image of the) products in billboards.

In terms of advertising marketing, what Toscani does is to build and cultivate the brand awareness, that is, the way the brand (in this case, Benetton) is perceived by the public in general. The novelty of the solution is that Toscani has extended this formula to everything that means advertising for the Italian company, avoiding any form of direct product promotion, either visual or verbal. Thus, the power of the brand becomes an expressive priority over the products represented. Obviously, the quality of the informed public of consumers, or the existence of a public awareness that has gone beyond the moment of initial information on the commercial nature of Benetton products, must be taken into account ${ }^{4}$. And yet, the condition of the author brings into question the dispute between the company producing the advertisement and its actual creator (or executor). That the originality of this approach belongs to Oliviero Toscani, is an indisputable fact. It shows, on the one hand, both the artist's activity outside the collaboration with Benetton (and its subsequent one), and the company's attempts to (re)produce similar advertising campaigns after 2000 (more precisely, after it interrupted the collaboration with Toscani). Oliviero Toscani's originality lies in the nature of his advertising approach, more precisely of the subjects and their relationship with the advertising approach. Defying conventions, overcoming social barriers and taboos, the artist constructs works whose value transcends the advertising dimension of the construct, to the artistic one. At the level of the semiotic mechanism, Toscani fulfills one of the fundamental premises of the definition of advertising as visual art, namely the distinction between the signaling and the symbolizing functions of the expressive construct ${ }^{5}$. Through symbolic evocation, art manages to access a semantic field of a specific expressive consistency ${ }^{6}$. In advertising, this landmark of symbolism is added to the signaling function that has the persuasive ability to achieve,

\footnotetext{
${ }^{4}$ C. Soreanu, Artă şi publicitate. Medii de expresie în publicitatea contemporană. Iași: Artes, 2018.

${ }^{5}$ R. Barthes, Rhetoric of the image. New York: Hill \& Wang, 1985.

${ }^{6}$ M. Tarași, Sens şi expresie in arta contemporană. Iași: Artes, 2006: p.185.
} 
through precision and success, a very clear semantic register (hence the space-time identification that defines advertising).

\section{The campaigns for Benetton}

The works of the Benetton campaigns from 1982 to 2000 managed to arouse the public's interest by appealing to topics such as eroticism and sexual taboos, racism, psychosis caused by AIDS, anorexia, or themes such as ecology or armed inter-ethnic conflicts. From a visual syntactic point of view, the tensions reside only in the formal association of the subject with the Benetton logo box, so from the re-signification of a concept in the conditions of the advertising expression. This mutation of meaning is, in fact, apparent, marking a level of normality of perceptions that society, in its pursuit of consumerism, entertainment and industrialization, no longer associates with normal (non-alienated) behaviour.

Toscani's works return, under the pretext of advertising, an immanent direction of normality to humanity, towards real aspects of human existence. This awareness and sensitization of public perception is what ideologically defines the advertising process of Oliviero Toscani, who almost reverses the relationship and transfer of identity between the artistic approach and the advertising carrier: not products are promoted by Toscani's art, but his works are promoted through these advertising campaigns. The logic is also supported by the exceptional addressability of his works in the commercial advertising repertoire, by the dedicated and open-minded public, and by another mutation that takes place at the level of the advertising act since the '60s, together with the American Pop-Art ${ }^{7}$. This mutation restores the quality of "being art" to advertising, by moving away from clichés and stereotypes, and by the appropriation of dedicated artistic standards and techniques.

Toscani's favourite themes are the liminal subjects of contemporary society, which the artist's agile sense of observation identifies and materializes in his works. The active contextual interpretation of public's reading recommends them as cultural idioms whose universality is disputed at the level of questioning the elementary conditions of humanity. In the case of the advertising campaign where he used photos of the death row inmates in American prisons ${ }^{8}$, Benetton made an extremely risky bet with the

\footnotetext{
${ }^{7}$ A point of interest of Olivero Toscani's "pedigree" is the relationship with Andy Warhol, an emblematic figure of American Pop Art, whose activity has crossed several decades of postmodern and contemporary art. (https://klatmagazine.com/en/photography-en/oliviero-toscaniinterview-back-to-the-future-06/37739 (accessed 02/28/2021).

8 "Bitterly attacked by some and internationally acclaimed by others, Benetton's campaigns have managed to tear down the wall of indifference contributing at raising the awareness of universal problems among world's citizens." Benetton's Press Release. Online source: http://www.benettongroup.com/media-press/press-releases-and-statements/looking-at-deathin-the-face/ (accessed 3/1/2021).
} 
consumer market, in which it assumed not only the inherent risks of any advertising campaign, but also those of taking a position and of the moral load of the meanings that the works can acquire in different reception environments. ${ }^{9}$ Controversial topics are generally suppressed in modern societies and become taboo topics, and Oliviero Toscani's practice is thus oriented towards understanding and overcoming these difficulties. There is a deep humanistic intent in his work, a direction that expressively enriches Benetton's campaigns, shifting the emphasis from the company's products (non-existent as an image) to building an identity and an awareness with which the Benetton customer is invited to identify.

\section{Critical reading of Benetton advertisements}

Toscani's works for Benetton are subject to interpretation from the perspective of several criteria of the advertising general approach:

a) They are works that, by their very nature, are addressed to an international, globalized public, although the reception and interpretation of advertisements (hence their meaning) is done realized at the level of addressing the specificity of each culture in part. Oliviero Toscani's ads resonated among the most diverse in the world, ranging from thunderous success (in some European states) to complete bans and even street demonstrations against the Benetton campaign and its products in other states (US or Islamic states);

b) These works are disseminated through contemporary media, which leads (more and more) to the elimination of time and space differences (these are campaigns presented simultaneously all over the world, from Hong Kong to Ottawa);

c) The Benetton ads address a capitalist society, against the background of globalization, convergence and world economic synergy ${ }^{10}$. From totalitarian, expansionist American capitalism to the emerging forms of pseudo-capitalism in Eastern Europe, Toscani's works manage to arouse the same vivid interest, raise questions, and give rise to controversy;

d) Toscani's images have a profound humanistic character, promoting equality in rights, humanity and tolerance, addressing to the society of the '90s going through the post-racial crisis, acceptance and awareness of the AIDS threat, post-communist crisis, and national-ethnic crisis of the division of ex-communist federal states. Benetton's

\footnotetext{
${ }^{9}$ The reaction of retail chains such as Sears and Roebuck\&Co was to boycott and refuse to sell Benetton products.

(https://www.theguardian.com/media/2001/jun/18/advertising.marketingandpr (accessed 3/1/2021)

${ }^{10}$ Marita Sturken, and Lisa Cartwright. Practices of looking, an introduction to visual culture. NY: Oxford University Press, 2001: p. 315.
} 
advertisements are addressed to a tense society and respond to it through visual constructions that show deep concern and involvement in identifying, accepting and solving serious social issues.

\section{The campaign "Shock of Reality"}

The 1980s marked, for advertising companies, the removal of iconized, commercial images from industry clichés. Companies such as Gap, Esprit or Workers of Freedom started to use images of ordinary people in advertisements for their products ${ }^{11}$, while the advertising company Howell, Henry, Chaldecott, Lury (HHCL) made a TV campaign for Fuji Film that aimed to eliminate social stereotypes by using images of marginalized people, retirees, Asians, the disabled ${ }^{12}$. Along these lines, Benetton's "Shock of Reality" campaign proposed the reconsideration of the usual type of advertising by using images of often shocking realism, images taken from the media or from the portfolio of photojournalists active in conflict zones around the world, associated in a completely atypical solution for the advertising industry ${ }^{13}$. If the established form of commercial advertising aims to achieve a persuasive effect, whatever the method (creating a desirable field, association with the brand ethos, product promotion, designing its advantages, etc.), the campaign signed by Oliviero Toscani is on a completely different direction of action: raising public awareness and raising social awareness by observing and exposing to the immediate realities, whatever their nature: political, racial, sexual, discriminatory, etc.

Benetton's "Shock of Reality" campaign was produced by Oliviero Toscani and included a series of posters and billboards made by including appropriated images from the media (printed press and TV news), iconic sequences for contemporary issues, with high impact and gravity, such as: the image of a dying patient of AIDS, a burning car in Mafia-dominated southern Italy, an electric chair waiting for US death row inmates, an execution or an environmental disaster, the bloody uniform of a Bosnian soldier, all in all subjects and themes used beyond the conventional borders of commercial advertising imagery. The display of the vulnerable, sick, or raped human body is a compositional strategy of using the abject as a unique artistic

\footnotetext{
${ }^{11}$ Helen Fielding, „Cashing in a World of Woe: Advertising.” Sunday Times, 29 September 1991.

${ }^{12}$ Kate Muir, „On the Banned Wagon: Life and Times.” The Times. London: Times Newspapers Ltd, 6 June 1991.

${ }^{13}$ A brief overview of the campaigns from the 90 s will reveal ads with a concept of Oliviero Toscani, based on photos realized by journalists associated with major media companies, such as Franco Zecchini (Magnum), Steve McCurry (Magnum), Yves Gellie (Odyssey), Patrick Robert (Sygma) etc. (http://www.benettongroup.com/media-press/image-gallery/institutionalcommunication/historical-campaigns/ (accessed 3/2/2021).
} 
resource in the arts landscape of the twentieth century ${ }^{14}$, a strategy repeatedly used by Toscani in the advertising campaigns for Benetton.

The functional paradox of advertising is that these images come from the media, practically from an environment whose role is to bring them to the attention of the society. On the other hand, the advertising approach also appeals to the media to restore the consumer/receiver's attention to reality, to the actual dimension of the subject. The appropriation method thus works both at the level of the subject and at the level of the information disseminating in social environment.

\section{“AIDS - David Kirby” ad}

Part of the "Shock of Reality" campaign, the "AIDS - David Kirby" ad is based on a documentary photo realized in 1990 by the journalist Therese Frare, previously published in American Life magazine, depicting David Kirby on his deathbed, surrounded by his family ${ }^{15}$. Being an AIDS activist, Kirby founded the Stafford Ohio AIDS Foundation. He spent the last two months of his life at Pater Noster House, an alternative community home in Columbus (where Frare was actually working as a volunteer). Therese Frare's documentary focused not only on David Kirby, but also on Patrick Church (Peta), Kirby's caregiver. The documentary resulted in a photo series from which Oliviero Toscani chose the final photograph for the tragedy and its artistic potential. Oliviero Toscani negotiated the use of the image with Frare and obtained both the author's permission and the consent of the deceased's family, thus respecting his desire to (re)bring the issue of AIDS into public opinion ${ }^{16}$.

The artistic mechanism used by Toscani involved not only the appropriation of the image, but also the intervention on it: the image, initially black and white, was digitally coloured and Kirby's figure was retouched to resemble that of Christ. Thus, the image undergoes a process of contextual resignification, migrating from the protocol of journalistic realism to the traumatic tragedy of the advertising construct. This occurs not only by overturning the conventions related to the topics addressed in advertising and introducing those from the immediate, cruel and objective reality, but also by

\footnotetext{
14 "Abject Art" was the subject of a dedicated exhibition at the Whitney Museum of American Art in 1993, starting with Julia Kristeva's idea of the abject based on a Lacanian principle - a state of degradation, disgust - as an "attempt to categorize what cannot be categorized". (https://www.artspace.com/magazine/interviews_features/book_report/what-is-abject-art-tellme-thats-not-what-i-think-it-is-56210 (accessed 02 28, 2021)

${ }^{15}$ Therese Frare: "David Kirby on his deathbed" Ohio, 1990.

(https://www.life.com/history/behind-the-picture-the-photo-that-changed-the-face-of-aids/ (accessed 2/28/2021).

${ }^{16}$ Time.com. The Face of AIDS - Therese Frare. 1990. Online source: http://100photos.time.com/photos/therese-frare-face-aids (accessed 02/28/2021).
} 
the uncompromising use of representational codes in the documentary format, in advertising, especially in the commercial advertising.

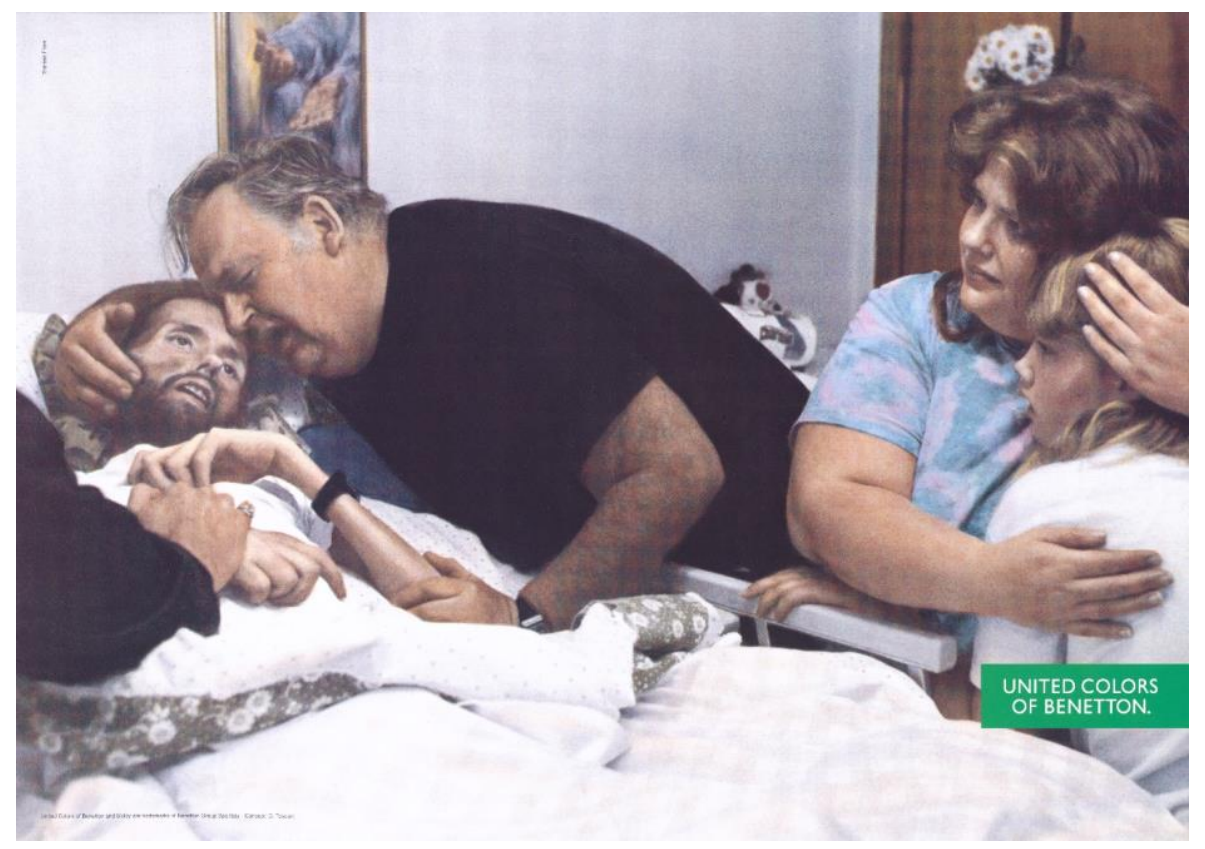

Fig. “AIDS - David Kirby”, 1992, for Benetton ${ }^{17}$. Concept: Oliviero Toscani. Photo: Therese Frare ("David Kirby on his deathbed", Ohio, 1990)

Toscani exploits the potential of a ready-made approach as a subversive strategy, not only as an imagistic appropriation from the avantgarde of advertising and pop art (heavily used by Andy Warhol in the '60s), but also as an iconographic viewpoint, creating cultural references which make a consistent shifting from the formal representation of an "abject" subject, to the theme of mortality, sacrifice and suffering (validating, in this way, the main artistic perspective). The activist strategy is obvious and it is validated both by the chosen subject (from the immediate reality, subject of maximum attention and importance), and by the method he used (appropriation and intervention). The fact that Toscani chooses an image from media, respectively a documentary photo, highlights the desire to draw attention to reality, stimulating a kind of reception specific to the area of the

\footnotetext{
${ }^{17}$ Oliviero Toscani, “AIDS - David Kirby”, 1992, for Benetton. Published with the written permission from Benetton. (C) Copyright Benetton Group - All rights reserved. (http://www.benettongroup.com/it/media-press/immagini/comunicazioneistituzionale/campagne-storichel (accessed 3/2/2021).
} 
documentary image and transferring it to the area of accepting commercial advertising.

In the case of the ad, Toscani not only changes the character of the original image (from documentary to artistic, thus shifting it from objectivity to activism), but also incorporates artistic visual strategies specific to Baroque painting. The aesthetic process included altering the image, colouring, retouching and accentuating the contrast in order to increase the expressive stake and recode the final meaning. Although it is apparently a diversion from the documentary character, the change of the image from black and white to colour has the immediate effect of accentuating the power of persuasion on a perceptive-realistic emotional basis.

Kirby's figure was slightly modified to emphasize the similarity with the suffering, crucified Christ-like image, adding even more to the controversy that this work created in the spectacle of consumer advertising. The original photo is taken in natural lighting conditions (the interior being a typical hospital), yet the resulting atmosphere is of the chiaroscuro type, chromatically enriched by Toscani's intervention, thus leaving the impression of Caravaggio's baroque. The expected effect of assimilating this subconscious cultural reference is maintained by the details of the compositional structure that projects the viewer into the atmosphere of the image, transforming him into a witness of the tragic event. Hence, the bed is placed in perspective, the priest's hand appears sideways, the figure of the father is bent over the suffering body, and so on.

On the wall behind the bed there is a partial image of Christ with his hand outstretched to the bed, which creates a relational tension together with the two major compositional centres in which the figures of the personages are touching, embracing, and protecting each other. With the father of the patient, and the hand of the priest present at the scene that concludes a first gestural path (the Son of God and the representative of God), the scene recalls the atmosphere of Christ's pain in Renaissance and Baroque religious paintings. The atmosphere, continued with the second attention-drawing center, in which the image gives full details of the mother comforting her daughter, restores the iconographic structure of a Pieta in which Mary mourns her son. In the first centre of interest, the substitution of Mary with the paternal figure of Kirby's father marks the contrast between the exhaustion of the dying, and the tragedy of the family, a contrast found in the tonal structure of the work between the two centres of interest.

Nevertheless, the main tension lies in the purpose of this work, namely that the whole composition is, in fact, an advertisement for Benetton brand clothing. The advertising success of the ensemble is undeniable, although its importance worked for Benetton only on commercial principles. The work marks a point of reference in postmodern advertising by introducing a media subject, a solution of artistic origin, and an act of 
resignification, whose scope goes far beyond the formal boundaries between art and advertising.

\section{Between notoriety and controversy}

The case of Therese Frare's photograph of David's family comforting him in the hour of his death ${ }^{18}$ brought both notoriety and controversy to the subject itself, equally reflected in Oliviero Toscani and Benetton's image. A wide range of reactions were counted: the Roman Catholics reacted against the suggested mockery of the classical image of Mary cradling Christ after the crucifixion ${ }^{19}$; AIDS activists reacted as well, seeing the entire situation as an attempt to exploit the death and the pain for commercial purposes; banning of the ad was asked for in England (being labelled offensive and unethical); various magazines refused to display the ad in their pages (Elle, Vogue and Marie Claire), as an attempt to boycott Benetton $^{20}$. However, in many regards, the success of the campaign was real and undeniable, and the ad sits nowadays in the gallery of the most controversial artistic approaches in advertising.

In terms of artistic practice, in "AIDS - David Kirby" Toscani's approach legitimizes the use of art-specific methods and content in advertising, (re)establishing the bridge between art and advertising, based on the structural landmarks of the common visual grammar that underlies these disciplines. Thus, contemporary advertising recovers the cleavage produced with the dissociation of artistic movements from commercial disciplines and the differentiation of the art of advertising ${ }^{21}$.

\section{Conclusions}

Carried out under the restrictive auspices of the market economy and having to respond to marketing reasons, advertising is seldom permissive for the artistic contribution of creators. Advertising has trends, involves recipes, clichés and solutions whose operation ensures concrete results, translated into

\footnotetext{
${ }^{18}$ The photography brought notoriety to Therese Frare as well, along with a World Press Photo Award in 1991. (https://www.worldpressphoto.org/collection/photo/1991/33397/1/1991-

Therese-Frare-GN2 (accessed 2/28/2021)

${ }^{19}$ C.Soreanu, „The Sacred In Contemporary Advertising.” Editor Codrina-Laura Ioniță, Puiu Ioniţă şi Brînduşa Grigoriu. ANASTASIS - Research in Medieval Culture and Art (Artes) 3, nr. 1 (2016): p.149-158.

${ }^{20}$ B.Cosgrove, The Photo That Changed the Face of AIDS. 2021.

(https://www.life.com/history/behind-the-picture-the-photo-that-changed-the-face-of-aids/ (accessed 02/28/2021).

${ }^{21}$ C.Soreanu, „From Media to Mediums of Expression. Visual Art Communication and Meaning." Editor Codrina-Laura Ioniță, Andreea-Irina Stoleriu şi Adrian Stoleriu. ANASTASIS - Research in Medieval Culture and Art (Artes) 7, nr. 2 (November 2020): p.261-276.
} 
positive turnovers. From this point of view, Toscani's authorial approach had the chance of an optimal configuration, materialized by ensuring a potential brand in development (United Colors of Benetton, the brand under which Benetton promoted their products in the 2000s), the artistic genius of the artist (Oliviero Toscani), a saturated advertising market bored with clichés (both European and international), but especially by the permissive and open attitude of the owner of the Italian company (Luciano Benetton), who gave "carte blanche" to Oliviero Toscani, fully confident in his potential to promote the company's image ${ }^{22}$.

In his interview under "Pushing the limits" chapter of Phaidon's "Advertising Today", Oliviero Toscani argues that the advertising “... could be an incredible art form. When you look back into history and look at Renaissance painting, that was like advertising painting in the church. The painters were called in to express a religious idea, which was like a product so the painting was there to promote a power, a king, a religion. But those Michelangelos and Leonardos were able to transcend all of that to become art. And we should do the same." ${ }^{, 23}$ All of the advertising campaigns of the Italian company Benetton, designed and coordinated between 1982 and 2000 by Oliviero Toscani, managed to fulfill this desire of advertising (seen as an integral part of the visual arts family), to complete the expressive offer of art based on the recovery of traditional professional standards. Oliviero Toscani's works return to publicity the role of factor of public awareness and social reflection. Addressing controversial topics in unique ways, despite social behavioural rules and canons, his advertisements demonstrate that quality advertising can be a construction with a remarkable semantic magnitude which is specific, in general, to art.

\section{Bibliography:}

Artspace. „What Is Abject Art? (Tell Me That's Not What I Think It Is...).”

ArtSpace.com., 14 August 2019.

https://www.artspace.com/magazine/interviews_features/book_report/what-is-abjectart-tell-me-thats-not-what-i-think-it-is-56210 (accessed 02/28/2021).

Barthes, Roland, Rhetoric of the image, New York: Hill \& Wang, 1985.

Berger, Warren, Advertising Today, New York: Phaidon Press, 2001.

Cosgrove, Ben, The Photo That Changed the Face of AIDS, 2021.

https://www.life.com/history/behind-the-picture-the-photo-that-changed-the-face-ofaids/ (accessed 02/28/2021).

\footnotetext{
${ }^{22}$ Although ended in 2000 (and briefly resumed between 2017-2020), the collaboration between Toscani and Benetton still has profitable resonances for the later, the company continuing to devise marketing strategies on controversial topics.

(http://www.benettongroup.com/media-press/ (accessed 2/28/2021)

${ }^{23}$ Berger, Warren. Advertising Today. New York: Phaidon Press, 2001.
} 
Del Drago, Elena, Interview Oliviero Toscani: Back to the future (\#06), 26 February 2013. https://www.klatmagazine.com/en/photography-en/oliviero-toscani-interviewback-to-the-future-06/37739 (accessed 02/28/2021).

Fielding, Helen, „Cashing in a World of Woe: Advertising”, Sunday Times, 29 September 1991.

Lyman, Eric J., The True Colors of Oliviero Toscani, August 2001. http://www.ericjlyman.com/adageglobal.html (accessed 02/28/2021).

Muir, Kate, „On the Banned Wagon: Life and Times.” The Times. London: Times Newspapers Ltd, 6 June 1991.

Soreanu, Catalin, Artă și publicitate. Medii de expresie în publicitatea contemporană, Iași, Ed. Artes, 2018.

Soreanu, Catalin. „From Media to Mediums of Expression. Visual Art Communication and Meaning." Editor Codrina-Laura Ioniță, Andreea-Irina Stoleriu şi Adrian Stoleriu. ANASTASIS - Research in Medieval Culture and Art (Artes) 7, nr. 2 (November 2020): 261-276.

Soreanu, Catalin. „The Sacred In Contemporary Advertising.” Editor CodrinaLaura Ioniță, Puiu Ioniţă și Brînduşa Grigoriu. ANASTASIS - Research in Medieval Culture and Art (Artes) 3, nr. 1 (2016): 149-158.

Sturken, Marita, și Lisa Cartwright. Practices of looking, an introduction to visual culture. NY: Oxford University Press, 2001.

Tarași, Mihai. Sens și expresie în arta contemporană. Iași: Artes, 2006.

Time.com. The Face of AIDS - Therese Frare. 1990. http://100photos.time.com/photos/therese-frare-face-aids (accessed 02/28/2021).

Toscani, Oliviero. Oliviero Toscani - Biography. 2021.

http://olivierotoscani.com/biografia_en.html (accessed 02/28/2021). 